OPEN ACCESS

Edited by:

Arnold Bosman

Transmissible Public Health

Support, Netherlands

Reviewed by:

Mathilde Crone,

Leiden University Medical

Center, Netherlands

Maria Vittoria Bulgheroni,

Ab.Acus, Italy

*Correspondence:

Maria Hägglund

maria.hagglund@kbh.uu.se

Specialty section: This article was submitted to

Digital Public Health,

a section of the journal

Frontiers in Public Health

Received: 25 October 2020 Accepted: 30 April 2021

Published: 08 June 2021

Citation:

Cijvat $C D$, Cornet $R$ and Hägglund $M$ (2021) Factors Influencing

Development and Implementation of

Patients' Access to Electronic Health Records - A Comparative Study of

Sweden and the Netherlands.

Front. Public Health 9:621210.

doi: 10.3389/fpubh.2021.621210

\section{Factors Influencing Development and Implementation of Patients' Access to Electronic Health Records-A Comparative Study of Sweden and the Netherlands}

\author{
Charlotte D. Cijvat ${ }^{1}$, Ronald Cornet $^{1}$ and Maria Hägglund ${ }^{2 \star}$ \\ ${ }^{1}$ Amsterdam Public Health, Medical Informatics, Amsterdam Universitair Medische Centra, University of Amsterdam, \\ Amsterdam, Netherlands, ${ }^{2}$ Department of Women's and Children's Health, Uppsala University, Uppsala, Sweden
}

Background: Patient-accessible electronic health records (PAEHRs) and associated national policies have increasingly been set up over the past two decades. Still little is known about the most effective strategy for developing and implementing PAEHRs. There are many stakeholders to take into account, and previous research focuses on the viewpoints of patients and healthcare professionals. Many known barriers and challenges could be solved by involving end-users in the development and implementation process. This study therefore compares barriers and facilitators for PAEHR development and implementation, both general and specific for patient involvement, that were present in Sweden and the Netherlands.

Methods: There were a total of 14 semi-structured interviews with 16 key informants from both countries, on which content analysis was performed. The Consolidated Framework for Implementation Research was used to guide both the construction of the interview guides and the content analysis.

Outcomes: The main barriers present in both countries are resistance from healthcare professionals and technical barriers regarding electronic health record systems and vendors. Facilitators varied across the two contexts, where the national infrastructure and program management were highlighted as facilitators in Sweden and stakeholder engagement (including patients and healthcare professionals) was described as a facilitator in both contexts. Strong leadership was also described as a critical success factor, especially when faced with healthcare professional resistance.

Conclusion: Most of the major barriers and facilitators from both countries are covered in existing literature. This study, however, identified factors that can be seen as more practical and that would not have arisen from interviews with patients or physicians. Recommendations for policymakers include keeping the mentioned barriers in mind from the start of development and paving the way for facilitators, mainly strict policies, 
learning from peer implementers, and patient involvement, when possible. Implementers should focus on strong decision-making and project management and on preparing the healthcare organization for the PAEHR.

Keywords: patient accessible electronic health record, open notes, patient portal, implementation, consolidated framework for implementation research

\section{INTRODUCTION}

Over the past two decades, advancements in law, technology, and policy have stimulated the implementation of patient-accessible electronic health records (PAEHRs) (1). These systems, set up by either healthcare providers or governments, allow patients to access their medical data whenever they want. PAEHRs can be designed and implemented in different ways, including logging in to a web-accessible portal to read the EHR information and potentially downloading this information into a personal health record (PHR). In the USA, a distinction is often made between access to, e.g., lab results and access to the actual notes in the record, with the latter referred to as open notes $(2,3)$. The concept PAEHR, on the other hand, refers to patients' access to all the content in the electronic health record (EHR) (1), including, but not limited to, clinical notes. Providing access to medical data potentially improves patient empowerment, leading to less consultations and more efficient healthcare provision, thus lowering healthcare expenditure and resulting in better health outcomes (4). Since these benefits can occur not only on an individual healthcare provider level but also for the whole healthcare system, many countries take a national approach to either developing national PAEHRs or creating national policies for implementation (5).

Even though more and more PAEHRs have been implemented, still little is known about the most effective strategy for developing and implementing PAEHRs and associated policy. Implementation can be defined as "the constellation of processes intended to get an intervention into use within an organization; it is the means by which an intervention is assimilated into an organization" (6). In the case of PAEHRs, there are many human, organizational, and technological factors that can complicate these processes (7). There are, for example, many different stakeholders affected by PAEHRs, all with different and sometimes contradictory concerns, incentives, or demands $(8,9)$. Existing literature mainly focuses on individual cases and on the viewpoints of patients $(10,11)$ or healthcare professionals (HCPs) (12) rather than the people responsible for developing or implementing PAEHR policy (13). Progress, internationally, has been slow due to legal constraints, technical challenges, and concerns or resistance among HCPs (14). Low rates of adoption among patients have also been a problem in some areas (14). Nonetheless, research evidence reports positive outcomes among patients accessing their records $(3,10)$, and the concerns expressed by HCPs have not been realized. Patients who read their notes report understanding their care plans better (3), feeling more in control of their care $(3,10)$, doing a better job taking their medications (15), improved communication with and trust in their clinicians $(10,15)$, and improved patient safety (16). Studies focusing on implementation barriers stress the importance of involving end-users' viewpoints-in this case, the patients-in the development and implementation $(4,17,18)$. For example, patient-reported barriers for PAEHR adoption include lack of healthcare provider acceptance, endorsement, and promotion of the PAEHR, poor user health literacy, and perceived usability and utility problems (e.g., usefulness of the available information and personalization of the PAEHR).

It has been hypothesized that countries developing PAEHRs and associated policies face similar barriers and facilitators, both general and specific, for patient involvement and can improve their existing policies by comparing these factors and learning from each other (19). We have chosen Sweden and the Netherlands as two contexts to explore and compare in this study. It is expected that the outcomes of this study can help Sweden, the Netherlands, and potentially other countries with similar strategies to improve their policies and strategies regarding PAEHR development and implementation. This study aims to:

1. describe and compare barriers and facilitators to implementing PAEHRs in Sweden and the Netherlands, and

2. describe and compare different aspects of patient involvement in PAEHR development and implementation processes in Sweden and the Netherlands.

\section{METHODS}

To compare the implementation of PAEHRs in Sweden and the Netherlands, we performed semi-structured interviews with key informants in the respective contexts, focusing on barriers and facilitators in the implementation process, as well as on issues specifically related to patient involvement.

\section{Study Settings}

The study settings presented in Table $\mathbf{1}$ were used as a guide for identifying the different stakeholders and key informants. Implementation of PAEHRs may consist of several parts; both PAEHR policy and the practical (often both technical and organizational) implementation, which will likely need to take place on both national and local (healthcare provider) levels (Figure 1).

Depending on the context, activities may vary between the national and local levels, both with respect to policy and practical implementation. The difference between Sweden and the Netherlands will be highlighted below.

\section{The Netherlands}

We chose to focus on the "Versnellingsprogramma Informatieuitwisseling Patiënt en Professional" (VIPP program) in the Netherlands. At the time of data collection, the program 
TABLE 1 | Overview of healthcare system structures, regulations concerning access to medical data, and existing patient-accessible electronic health record (PAEHR) policies in Sweden and the Netherlands.

\begin{tabular}{|c|c|c|}
\hline & Sweden & The Netherlands \\
\hline Number of inhabitants & 10 million & 17 million \\
\hline Healthcare system structure & $\begin{array}{l}\text { Tax-funded; decentralized: regional governments, } 21 \text { regions are } \\
\text { responsible for provision of care and may contract both public and } \\
\text { private providers }\end{array}$ & Mandatory private insurance; private care providers deliver care \\
\hline $\begin{array}{l}\text { Laws regarding (digital) access } \\
\text { to medical records }\end{array}$ & $\begin{array}{l}\text { All citizens aged } 16 \text { and over have a right to directly access } \\
\text { different types of health documentation }{ }^{\text {a }}\end{array}$ & $\begin{array}{l}\text { Patients aged } 12 \text { and over have a right to a digital copy of all } \\
\text { information included in the record when the data is processed } \\
\text { digitally (from July 2020) }\end{array}$ \\
\hline PAEHR policy & $\begin{array}{l}\text { One PAEHR for all citizens: Journalen, which was developed by } \\
\text { Region Uppsala in several projects since } 1997 \text { (5). All regions } \\
\text { agreed to implement Journalen as part of the national } 1177 \\
\text { Healthcare Guide patient portal. It collects data from different EHR } \\
\text { systems through a Health Information Exchange (HIE) } \\
\text { infrastructure. There are national guidelines, the National } \\
\text { Regulatory Framework (NRF), but it is not mandatory to follow }\end{array}$ & $\begin{array}{l}\text { From December } 2016 \text { to December 2019, the } \\
\text { "Versnellingsprogramma Informatieuitwisseling Patiënt en } \\
\text { Professional" (VIPP program) is in operation. It aims to promote } \\
\text { general hospitals and other specialist care institutions to provide } \\
\text { digital access and improve medication safety. Participation is not } \\
\text { mandatory, but a financial incentive is awarded when specific } \\
\text { goals are met }\end{array}$ \\
\hline Choices in implementation & $\begin{array}{l}\text { The first version of the NRF included both mandatory and electable } \\
\text { paragraphs. The main decisions for regions were regarding } \\
\text { displaying record entries with or without signing by the physician } \\
\text { and with or without a 14-day delay (20). In } 2016 \text {, a new version of } \\
\text { the NRF was published with the intention to provide patients with } \\
\text { access to all health and dental care information by } 2020\end{array}$ & $\begin{array}{l}\text { Hospitals can choose which goals regarding patients' access, } \\
\text { standardized data capture, and medication verification they want } \\
\text { to implement' }{ }^{\mathrm{C}} \text {. Providing access is allowed by implementing a } \\
\text { patient portal or an upload of EHR information into a PHR. } \\
\text { Besides VIPP's goals, choices can be made regarding the history } \\
\text { of displayed data, whether information is displayed with or without } \\
\text { delay, and the potential functionalities of the portal }\end{array}$ \\
\hline Responsible organizations & $\begin{array}{l}\text { Inera AB manages the national patient portal } 1177 . \text { se, including } \\
\text { the PAEHR Journalen. It is a company owned by the Swedish } \\
\text { regional governments. Regions are responsible for connecting } \\
\text { their EHR systems to the national HIE }\end{array}$ & $\begin{array}{l}\text { The Ministry of Health, Welfare, and Sports and the Dutch Hospital } \\
\text { Association (NVZ) developed the subsidy program } \\
\text { Individual hospitals carry out the implementation by making } \\
\text { arrangements with their EHR system supplier }\end{array}$ \\
\hline State of the art & $\begin{array}{l}\text { As of March 2018, all regions have connected to the HIE and } \\
\text { implemented the PAEHR Journalen. However, some private } \\
\text { healthcare providers are still not connected }\end{array}$ & $\begin{array}{l}66 \text { out of } 70 \text { non-academic hospitals are participating in VIPPd. In } \\
\text { December } 2017,30 \text { out of } 78 \text { Dutch hospitals had a patient portal } \\
\text { with access to medical data }\end{array}$ \\
\hline
\end{tabular}

${ }^{a}$ https://inera.atlassian.net/wiki/spaces/OIJ/pages/438700782/Nationellt\%2Bramverk\%2Bf\%2Br\%2BJournalen.

${ }^{b}$ https://www.rijksoverheid.nl/binaries/rijksoverheid/documenten/brochures/2017/06/01/elektronische-gegevensuitwisseling-in-de-zorg/Wet+elektronische+verwerking+van+ gegevens+20170620.pdf

${ }^{c}$ https://www.vipp-programma.nl/over-vipp/doelstellingen.

${ }^{d}$ VIPP 1 Resultatentabel meting maart 2018: https://drive.google.com/file/d/1qe_owm3U0I2D-osz4Fw413ZIFIXDdxDw/view.

${ }^{e}$ nictiz.siw-ontwikkeling.n//blog/online-inzage-groeit-door/\#.

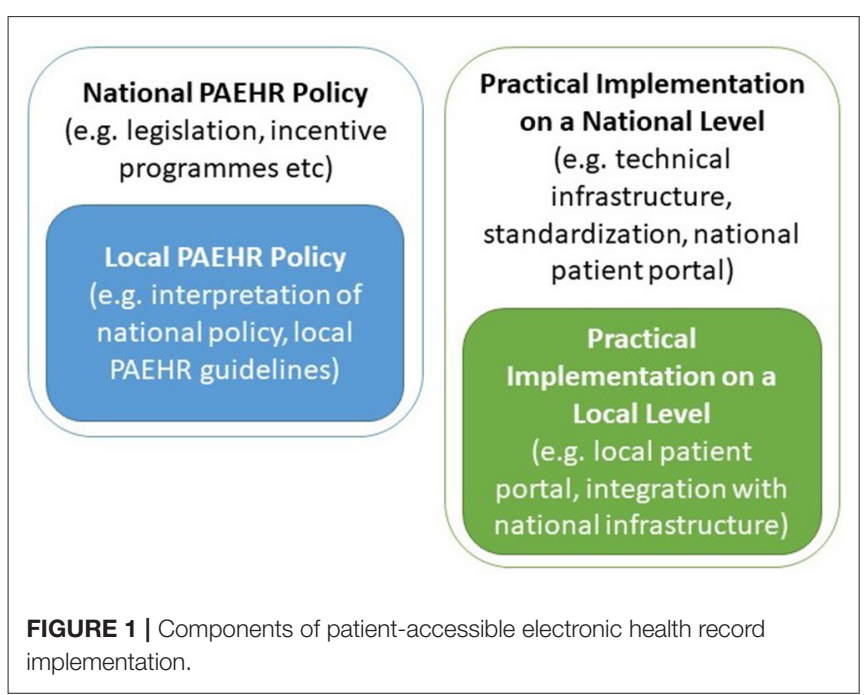

was in its first phase, which lasted until 2019. It aimed at promoting general hospitals to ensure patients' digital access to medical data and improve medication safety. Participation was not mandatory, but a financial incentive was awarded when hospitals met specific goals of their own selection. Since then, the program has progressed to include other types of healthcare providers and to focus on standardized registration of medical information. Currently, the program is in its fifth phase, which will run until July 2023. Each local healthcare provider is responsible for developing and implementing their online patient portals, and therefore describing them in more detail is difficult.

The VIPP program mainly includes policy on the national level, whereas both policy adaptions, e.g., choice of goals to focus on, and practical implementations, e.g., setting up an online patient portal, occur on the local (hospital/healthcare provider) level.

\section{Sweden}

In Sweden, 21 regions are responsible for providing healthcare. Although the regions are autonomous and can prioritize which eHealth services to focus on, the national eHealth strategy stipulates that there should be only one online healthcare access point for patients (21). Therefore, a national patient portal, "1177.se," has been implemented (5). The portal runs on a 
national health information exchange (HIE) platform $(22,23)$, and through this infrastructure, data stored in any of the EHR systems used in the 21 regions can be accessed. Authentication with an e-ID gives patients access to a number of administrative services as well as the PAEHR Journalen.

In Sweden, policy is important both on the national and local levels, with a national regulatory framework (NRF) for PAEHR $(20,24)$, which is adapted on the local/regional level. In contrast to the Netherlands, practical implementation, however, also takes place on both the national and the local level, with the bulk being on the national level with the national HIE platform, the national patient portal, and the national PAEHR. On the local level, practical implementation in Sweden is limited to connecting the local EHR system with the national HIE platform.

Similar to the Swedish context, national patient portals are implemented throughout the Nordic countries, whereas healthcare-provider-specific portals are common beyond the Nordic context, such as in the Netherlands. The Swedish and Dutch cases in this study therefore represent two different approaches that countries take to ensure that citizens have access to their health information. Table 1 gives an overview of the two contexts.

It is important to note that the Dutch VIPP only covers general hospitals and other specialist care institutions, while the Swedish PAEHR “Journalen" can display EHR data from all levels of healthcare. We distinguish developers of national PAEHR policies and solutions from local or regional healthcare providers that implement those.

\section{Study Participants}

We purposefully chose key informants in both contexts that could provide insights into the research questions. Personal and professional networks were used in Sweden, and in the Netherlands, the participants were recruited through the VIPP organization. An element of snowball sampling was also applied, where the initially identified key informants recommended others. In total, 16 key informants chose to participate in the study (see Table 2 for a description of the respondents' roles).

In Sweden, the original developers of the PAEHR Journalen from Region Uppsala, the current responsible organization Inera $\mathrm{AB}$, and other regions and healthcare providers that have implemented the PAEHR Journalen were approached. In the Netherlands, we interviewed the decision-makers of the VIPP program and experienced experts of implementing PAEHRs according to VIPP. In this study, we focused on the project managers' and implementers' perspective, not those of patients and HCPs which have been covered more extensively in the literature already.

\section{Data Collection}

Semi-structured interviews were conducted between March and May 2018 via Skype or phone, where possible. All interviews with Dutch respondents were conducted in Dutch. All interviews were performed by the first author, who speaks Dutch but not Swedish. Some Swedish respondents were reluctant to conduct the interviews in English and were offered to (iteratively) answer questions via email in Swedish. Their answers were translated
TABLE 2 | Overview of the interview respondents.

\begin{tabular}{|c|c|c|c|}
\hline Interview & Respondent & Organization & $\begin{array}{l}\text { Role related to } \\
\text { patient-accessible electronic } \\
\text { health record }\end{array}$ \\
\hline \multicolumn{4}{|l|}{ Sweden } \\
\hline 1 & 1 & Inera & Head of Journalen \\
\hline 2 & 2 & Region Uppsala & $\begin{array}{l}\text { Project manager/coordinator in } \\
\text { several projects of Journalen } \\
\text { development and } \\
\text { implementation }\end{array}$ \\
\hline 3 & 3 & Region Uppsala & $\begin{array}{l}\text { Medical expert involved in } \\
\text { several projects of Journalen } \\
\text { development and } \\
\text { implementation }\end{array}$ \\
\hline $4^{a}$ & 4 & Region 2 & $\begin{array}{l}\text { Project leader of Journalen } \\
\text { implementation }\end{array}$ \\
\hline $5^{a}$ & 5 & $\begin{array}{l}\text { Region } 2 \\
\text { Private caregiver }\end{array}$ & $\begin{array}{l}\text { Member of steering committee } \\
\text { for Journalen implementation } \\
\text { Chief medical informatics officer }\end{array}$ \\
\hline $6^{a}$ & $6,7,8$ & Region 2 & $\begin{array}{l}\text { Participant in central work of } \\
\text { Journalen implementation }\end{array}$ \\
\hline 7 & 9 & Region 3 & $\begin{array}{l}\text { Project leader for healthcare IT } \\
\text { implementation }\end{array}$ \\
\hline 8 & 10 & University & Researcher \\
\hline \multicolumn{4}{|c|}{ The Netherlands } \\
\hline 9 & 11 & $\begin{array}{l}\text { IT advising } \\
\text { company } \\
\text { Hospital } 1\end{array}$ & $\begin{array}{l}\text { Senior advisor } \\
\text { Project leader }\end{array}$ \\
\hline 10 & 12 & Hospital 2 & Project manager \\
\hline 11 & 13 & Hospital 3 & Project leader/advisor \\
\hline 12 & 14 & Hospital 4 & Project leader \\
\hline 13 & 15 & $\begin{array}{l}\text { VIPP program } \\
\text { Dutch hospital } \\
\text { organization }\end{array}$ & $\begin{array}{l}\text { Project leader Senior } \\
\text { policy advisor }\end{array}$ \\
\hline 14 & 16 & Patient federation & Policy advisor \\
\hline
\end{tabular}

a The interview was performed via email.

into English with the help of a native Swedish speaker. The remainder of the Swedish respondents participated in English. This applied to interview numbers 4-6 (marked in Table 2) with five respondents.

Semi-structured interview guides were established for each respondent separately based on their role and the context they practice in. The interview guide revolved around the following topics:

- factors affecting the implementation: perceived barriers and facilitators, and

- patient involvement: necessity, ideal execution, execution in reality, outcomes, and consequences

The interview guides were based on the Consolidated Framework for Implementation Research (CFIR), which identifies five dimensions that are essential to implement an intervention (6). An overview of the CFIR dimensions and sub-constructs is given in Figure 2.

The framework further provides sub-constructs and related questions for each of the dimensions (6). The structure of the 


\section{Consolidated Framework of Implementation Research (CFIR)}

\section{Intervention}

characteristics

\begin{tabular}{|ll}
\hline - & Intervention source \\
- & Evidence strength \\
& and quality \\
- & Relative advantage \\
- & Adaptability \\
- & Trialability \\
- & Complexity \\
- & Design quality \\
- & Cost \\
\hline
\end{tabular}

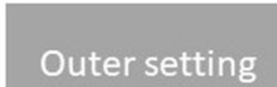

- Patients needs and resources

- Cosmopolitanism

- Peer pressure

- External policies and incentives

\section{Inner setting}

- Structural

characteristics

- Networks and

communication

- Culture

- Implementation

climate

\section{Characteristics \\ of individuals}

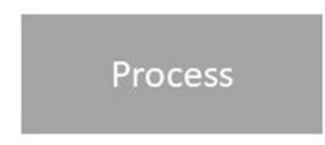

- Knowledge and
beliefs about the
intervention
- Self-efficacy
- Individual stage of
change
- Individual
identification with
organization
- Other personal
attributes

- Planning

- Engaging

- Executing

- Reflecting and

evaluating

FIGURE 2 | Overview of the consolidated framework for implementation research.

TABLE 3 | Barriers on the national level.

\begin{tabular}{|c|c|c|}
\hline Category & Sweden & The Netherlands \\
\hline $\begin{array}{l}\text { Systems and } \\
\text { suppliers }\end{array}$ & Authentication methods & $\begin{array}{l}\text { Difficulties in measuring } \\
\text { hospitals' progress }\end{array}$ \\
\hline $\begin{array}{l}\text { Social and } \\
\text { organizational }\end{array}$ & $\begin{array}{l}\text { Resistance and fears from } \\
\text { physicians }\end{array}$ & - \\
\hline \multirow[t]{2}{*}{ Resources } & $\begin{array}{l}\text { Financing the development } \\
\text { of Journalen }\end{array}$ & - \\
\hline & $\begin{array}{l}\text { Too little time to take } \\
\text { precautions for physicians' } \\
\text { resistance }\end{array}$ & \\
\hline \multirow[t]{3}{*}{$\begin{array}{l}\text { Policies, laws, and } \\
\text { regulations }\end{array}$} & $\begin{array}{l}\text { Include electable rules to } \\
\text { make progress }\end{array}$ & $\begin{array}{l}\text { Challenging to define goals } \\
\text { adequately for desired } \\
\text { outcomes }\end{array}$ \\
\hline & $\begin{array}{l}\text { Electable rules caused } \\
\text { confusion and inequality for } \\
\text { users }\end{array}$ & $\begin{array}{l}\text { Challenging to estimate } \\
\text { reasonable usage } \\
\text { percentages }\end{array}$ \\
\hline & $\begin{array}{l}\text { Giving patients direct online } \\
\text { access to the record was } \\
\text { illegal when the PAEHR } \\
\text { Journalen was first } \\
\text { introduced in } 2002\end{array}$ & $\begin{array}{l}\text { Slow development of other } \\
\text { national programs }\end{array}$ \\
\hline \multirow[t]{2}{*}{ Effects of barriers } & Delays & Delays \\
\hline & $\begin{array}{l}\text { Restrictions on information } \\
\text { that is displayed }\end{array}$ & \\
\hline
\end{tabular}

interview guides was determined by the sub-constructs that were deemed relevant for each type of respondent, i.e., respondents on the national or local level for both Sweden and the Netherlands.

To inquire about the factors affecting PAEHR implementation, the following selection of (sub)constructs was used: the strength and quality of evidence for the intervention, the external policies and incentives, the implementation climate, and all stages of the process (planning, engaging, executing, reflecting, and evaluating). The constructs that patient needs and resources and tension for change were used to assess the involvement of patients.

In addition, several other sub-constructs were selected for specific respondent types, such as peer pressure among Swedish regions. The questions proposed by the CFIR framework were adapted to each individual respondent's specific context. The interview guides were further improved iteratively after each interview to ensure that all relevant aspects were covered.

All participants were informed about the goals and risks of the study. If applicable, audio was recorded, and notes were kept. The interviews were transcribed as soon as possible using intelligent verbatim transcription. While listening to the recordings, transcripts were shortened and edited for the sake of clarity before analysis.

\section{Analysis}

The interviews were analyzed by means of content analysis according to Taylor-Powell and Renner (25). The selected CFIR constructs and sub-constructs formed the basis of the codes with which relevant passages from the edited transcripts were categorized. All passages were provided with a condensed meaning unit in English. Related passages and condensed meaning units were collected, compared, grouped, and provided with a description.

\section{RESULTS}

The results of our analysis are presented in two sections;

1. analysis of barriers and facilitators to implementation of PAEHRs, and 
2. the level and impact of user involvement in the respective setting.

\section{Factors Affecting the Implementation of PAEHRs}

We have identified the main barriers and facilitators to developing and implementing national PAEHR policy as described by the respondents from both countries. Barriers exist both on the national level (Table 3) and on the local implementation level (Table 4). One of the main barriers has been resistance from HCPs on both levels in Sweden and on the local implementation level in the Netherlands. This resistance is very much in line with concerns that have previously been described in the literature; concern that patients will misunderstand, take offense or worry unnecessarily, concern that the workload will increase with patients asking questions, and concern that the records' value will be reduced as it can no longer be used as a tool for professional communication.

"[...] one of the barriers was the healthcare professionals, especially the physicians' professional organization/union. The professional organization was more reluctant to expose it to the patient than the average doctor, is my opinion. Because they wanted to be in control of what the patient read. The legislation says it should not be hidden to the patient, with two exceptions: if someone else is mentioned in the record or if it is proven that the result of a treatment will be worse if the patient is aware of it, then the record can be closed. More or less, I have not found any doctor that has used any of those two reasons for not sending a copy on request of the patient." (Sweden, local level)

Regarding policy, both countries had some challenges on the national level. In Sweden, it was difficult to agree on a NRF, and the first version had several "electable rules," i.e., rules where each region or local healthcare provider had to choose how to implement (20). One could, e.g., choose which types of information to release to patients (notes, lab results, referrals, etc.), also whether to give immediate access or have a 2-week waiting period, and whether to release only signed/validated information or not. This, of course, led to a fragmentation of the otherwise national PAEHR, where it was difficult for patients to understand why they could see lab results from Region A but not from Region B. In the Netherlands, all practical implementation took place at the local level, but the VIPP program provided an important incentive. Here it was, however, difficult to both define goals and measure the hospitals' progress toward these goals.

"So, at the very last moment we thought, oh, something with an auditor and a manual is also still necessary. You can see that hospitals want to know everything down to the decimal point: what is meant with this, what do you want to achieve with that? [...] You see that such a manual in auditor language is difficult to interpret for hospitals." (the Netherlands, national level)

"I wonder whether the VIPP program actually delivers what it aims to deliver. This is mainly due to the audit questions, which are very technically structured: is this available, do you offer this...? I think that the reality in the workplace has not been looked at very carefully, whether these audit standards
TABLE 4 | Barriers on the local implementation level.

\begin{tabular}{|c|c|c|}
\hline Category & Sweden & The Netherlands \\
\hline \multirow[t]{4}{*}{$\begin{array}{l}\text { Systems and } \\
\text { suppliers }\end{array}$} & $\begin{array}{l}\text { Technical limitations of } \\
\text { systems }\end{array}$ & $\begin{array}{l}\text { Limitations in choice and } \\
\text { possibilities of systems }\end{array}$ \\
\hline & $\begin{array}{l}\text { High costs for connecting } \\
\text { small EHR systems }\end{array}$ & $\begin{array}{l}\text { Large dependency on } \\
\text { software suppliers }\end{array}$ \\
\hline & $\begin{array}{l}\text { Testing prior to } \\
\text { implementation necessary }\end{array}$ & $\begin{array}{l}\text { Alignment of systems } \\
\text { necessary but difficult }\end{array}$ \\
\hline & $\begin{array}{l}\text { Difficult requisites for } \\
\text { connecting to the HIE }\end{array}$ & $\begin{array}{l}\text { Systems and suppliers } \\
\text { determine achievement of } \\
\text { VIPP }\end{array}$ \\
\hline \multirow[t]{5}{*}{$\begin{array}{l}\text { Social and } \\
\text { organizational }\end{array}$} & $\begin{array}{l}\text { Resistance and fears from } \\
\text { physicians }\end{array}$ & $\begin{array}{l}\text { Physicians' reluctancy, } \\
\text { resistance, and fears }\end{array}$ \\
\hline & $\begin{array}{l}\text { Changing HCPs' routines, } \\
\text { workflows and attitudes }\end{array}$ & $\begin{array}{l}\text { Changing HCPs' political } \\
\text { status and workflow }\end{array}$ \\
\hline & & $\begin{array}{l}\text { Effects on hospitals' culture } \\
\text { and work processes }\end{array}$ \\
\hline & & $\begin{array}{l}\text { Fears for patients' } \\
\text { confusion, questions, fears }\end{array}$ \\
\hline & & $\begin{array}{l}\text { Gradual implementation } \\
\text { necessary to keep } \\
\text { physicians on board }\end{array}$ \\
\hline \multirow[t]{3}{*}{ Resources } & $\begin{array}{l}\text { High costs for connecting to } \\
\text { the HIE }\end{array}$ & $\begin{array}{l}\text { VIPP requires a lot of human } \\
\text { work }\end{array}$ \\
\hline & $\begin{array}{l}\text { Time-consuming decision } \\
\text { making due to flexibility in } \\
\text { NRF }\end{array}$ & $\begin{array}{l}\text { Human work leads to high } \\
\text { costs }\end{array}$ \\
\hline & & $\begin{array}{l}\text { Too little time to make } \\
\text { VIPP's deadlines }\end{array}$ \\
\hline \multirow[t]{3}{*}{$\begin{array}{l}\text { Policies, laws, } \\
\text { and regulations }\end{array}$} & & $\begin{array}{l}\text { Some VIPP goals are } \\
\text { difficult to accomplish }\end{array}$ \\
\hline & & $\begin{array}{l}\text { Strict privacy regulations not } \\
\text { in patients' interests }\end{array}$ \\
\hline & & $\begin{array}{l}\text { Strict security rules impede } \\
\text { user-friendliness }\end{array}$ \\
\hline \multirow[t]{3}{*}{ Governance } & $\begin{array}{l}\text { Gradual approach } \\
\text { necessary to get all } \\
\text { stakeholders on board }\end{array}$ & $\begin{array}{l}\text { Gradual implementation to } \\
\text { keep physicians on board }\end{array}$ \\
\hline & $\begin{array}{l}\text { Flexibility in choosing EHR } \\
\text { systems in some counties } \\
\text { but only one supported }\end{array}$ & VIPP has no or low priority \\
\hline & & $\begin{array}{l}\text { Cooperation between } \\
\text { stakeholders necessary }\end{array}$ \\
\hline \multirow{5}{*}{$\begin{array}{l}\text { Effects of } \\
\text { barriers }\end{array}$} & Delays & Delays \\
\hline & $\begin{array}{l}\text { Restrictions on information } \\
\text { that is displayed }\end{array}$ & $\begin{array}{l}\text { High costs for implementing } \\
\text { systems and VIPP }\end{array}$ \\
\hline & & $\begin{array}{l}\text { Too little time to create } \\
\text { support from staff }\end{array}$ \\
\hline & & $\begin{array}{l}\text { Low user-friendliness and } \\
\text { usage }\end{array}$ \\
\hline & & VIPP has low priority \\
\hline
\end{tabular}

match reality. And there is a lot of confusion." (the Netherlands, local level)

Implementers from both countries faced technical barriers when implementing PAEHRs. In Sweden, the first pilot projects 
TABLE 5 | Facilitators on the national level.

\begin{tabular}{|c|c|c|}
\hline Category & Sweden & The Netherlands \\
\hline \multirow[t]{2}{*}{$\begin{array}{l}\text { Systems and } \\
\text { suppliers }\end{array}$} & $\begin{array}{l}\text { Use of national HIE created by } \\
\text { another project }\end{array}$ & \\
\hline & $\begin{array}{l}\text { Previous experience and } \\
\text { knowledge }\end{array}$ & \\
\hline $\begin{array}{l}\text { Policies, laws, and } \\
\text { regulations }\end{array}$ & Stricter policy & \\
\hline Governance & $\begin{array}{l}\text { Decision-making on a political } \\
\text { level }\end{array}$ & \\
\hline
\end{tabular}

struggled to find secure authentication methods, but in later implementations, the technical challenges related mainly to connecting the EHR systems to the national HIE platform:

"The first barriers were strictly technical, making sure that we had the right protocols from the supplier of the EHR and making sure that everything worked fine in that integration." (Sweden, local level)

Connecting to the national HIE platform was not only described as a technical challenge; it could also be quite costly, which kept smaller private healthcare providers from connecting:

"[...] healthcare providers in our region can use whatever EHR system they want. It is expensive to make changes in the systems unless they are big. That's why there are healthcare providers who are still not connected. All hospitals and most health centers are connected." (Sweden, local level)

Dutch implementers were dependent on their IT suppliers for implementing a successful PAEHR and achieving the VIPP goals:

\begin{abstract}
"At the moment, we have a technological status in hospitals in the Netherlands; we have two suppliers who, kind of, wield the scepter, and we are therefore largely dependent on the speed at which they develop [the patient portals]. We have limited influence on that." (the Netherlands, local level)
\end{abstract}

The Dutch interviews revealed no facilitators on the national level, likely due to the fact that all practical implementations took place at the local hospital level. In Sweden, the National HIE platform as well as the updated, more strict version of the national regulatory framework (24) was described as facilitator (Table 5).

On the local implementation level (Table 6), the national infrastructure was also described as a facilitator in Sweden, with the use of national protocols and contracts making it easier for regions and private healthcare providers to integrate. Social aspects were also important Swedish facilitators, where involvement of different stakeholders, learning from peers who were also implementing, and a gradual implementation process were described as beneficial:

\footnotetext{
"It hasn't been so complicated to implement Journalen because our region was among the last to do it in Sweden. That means we could learn a lot from the experiences of those who had already implemented." (Sweden, local level)
}

TABLE 6 | Facilitators on the local implementation level.

\begin{tabular}{|c|c|c|}
\hline Category & Sweden & The Netherlands \\
\hline \multirow[t]{3}{*}{$\begin{array}{l}\text { Systems and } \\
\text { suppliers }\end{array}$} & $\begin{array}{l}\text { Use of national protocols } \\
\text { and standards }\end{array}$ & $\begin{array}{l}\text { Large EHR system suppliers } \\
\text { address security issues }\end{array}$ \\
\hline & $\begin{array}{l}\text { Reusable contracts and } \\
\text { protocols }\end{array}$ & $\begin{array}{l}\text { Portal functionalities existed } \\
\text { outside of healthcare }\end{array}$ \\
\hline & & $\begin{array}{l}\text { Think about future } \\
\text { development from the start }\end{array}$ \\
\hline \multirow[t]{5}{*}{$\begin{array}{l}\text { Social and } \\
\text { organizational }\end{array}$} & $\begin{array}{l}\text { Involve HCPs' perspective } \\
\text { in decision making }\end{array}$ & $\begin{array}{l}\text { Involve both patients and } \\
\text { professionals }\end{array}$ \\
\hline & $\begin{array}{l}\text { Communicate with } \\
\text { stakeholders }\end{array}$ & $\begin{array}{l}\text { NVZ published an analysis } \\
\text { of impact on hospitals' work } \\
\text { processes }\end{array}$ \\
\hline & Gradual implementation & \\
\hline & $\begin{array}{l}\text { Patients can change } \\
\text { physicians' behavior if no } \\
\text { one else will }\end{array}$ & \\
\hline & $\begin{array}{l}\text { Ambassadors in healthcare } \\
\text { organizations }\end{array}$ & \\
\hline \multirow[t]{2}{*}{ Resources } & $\begin{array}{l}\text { Learn from peers' } \\
\text { implementation processes }\end{array}$ & \\
\hline & $\begin{array}{l}\text { Previous experience and } \\
\text { knowledge }\end{array}$ & \\
\hline $\begin{array}{l}\text { Policies, laws, and } \\
\text { regulations }\end{array}$ & $\begin{array}{l}\text { Involve HCPs' perspective } \\
\text { in decision making }\end{array}$ & \\
\hline \multirow[t]{3}{*}{ Governance } & Implementing gradually & $\begin{array}{l}\text { Involve both patients and } \\
\text { professionals }\end{array}$ \\
\hline & $\begin{array}{l}\text { Dare to try despite fears } \\
\text { from professionals }\end{array}$ & Strong decision makers \\
\hline & $\begin{array}{l}\text { Central program } \\
\text { management }\end{array}$ & $\begin{array}{l}\text { Involve different } \\
\text { stakeholders: IT and } \\
\text { communication } \\
\text { departments, IT suppliers }\end{array}$ \\
\hline
\end{tabular}

Involvement of HCPs in the implementation process was described as a facilitator, but there were also some respondents who highlighted the importance of daring to proceed despite resistance from HCPs, indicating that this may be a doubleedged sword.

Strong decision-makers and involvement of different stakeholders (including patients and HCPs) were highlighted as facilitators in the Dutch context, too (Table 6):

"Involving HCPs very early and closely in decision-making is extremely important, so you want to treat them very nicely and carefully and never feel like you are making choices over their heads. There is still resistance to portals, and you can take that away by treating them properly. You can never take it away completely, so you have to be persistent. You also need a strong board of directors that make choices or someone else making choices and saying, we are going to do this, even if people are against it. You need that, too; it is also a critical success factor." (the Netherlands, local level)

"I think the success of this also depends on who gets involved, so if the board of directors finds this very important and gives it a lot of 'bravado', then it is more likely to lead to success. [... ] I think that is a success factor that you do not have [at this hospital], which means that the project is also running less than it could. 
[...] Because when the board of directors says: this is what we are going to do-then the specialists and medical managers and business managers will often listen much more carefully. Now, it is me who is always peddling. A hospital is quite hierarchical, which means that it is sometimes necessary for someone to say: this is what we are going to do." (the Netherlands, local level)

In the Dutch interviews, the EHR vendors' role was more prominent, and their contribution to addressing, e.g., security issues was considered a facilitator:

"Security is often addressed relatively late, like-oh, [the portal] also needs to be safe. That problem is somewhat smaller since we work with the large EHR suppliers because they already have their own ideas on that; they simply offer it in the safest possible way." (the Netherlands, local level)

Some facilitators and barriers were considered critical. In the Swedish context, the central management of the patient portal and HIE was seen as essential. In the Netherlands, involvement of end-users (both patients and HCPs), implementing toward a clear future goal, involvement of vendors and IT departments, and strong leadership were considered critical success factors. In the Dutch context, the dependence on collaboration with system vendors was also seen as a critical weakness.

\section{Patient Involvement}

The different aspects of patient involvement in PAEHR policy development and implementation in Sweden and the Netherlands are displayed in Table 7 (national level) and Table 8 (local implementation level). In Sweden, patients' wishes and preferences regarding digital access to the EHR were analyzed during the early deployment of the PAEHR Journalen. Regions implementing Journalen also attempted to do so but used fewer means to explore the patients' preferences. In addition, as most decisions relating to the national patient portal and the PAEHR were centralized to the national organization, there was a sense of loss of control on the local/regional level, making the incentives for engaging patients in decision-making limited. In the Netherlands, patient involvement mainly took place at the implementation level, even though hospitals face multiple barriers when doing so. Little to no patient involvement was carried out when developing VIPP.

\section{DISCUSSION}

\section{Principal Findings}

Swedish and Dutch developers and implementers of national PAEHR policy have reported on many different barriers, facilitators, critical success factors, and aspects of patient involvement. These outcomes are compared and linked to existing literature in order to interpret them and give recommendations.

\section{Barriers, Facilitators, and Critical Success Factors}

The main barrier that both countries face is resistance from HCPs, which is confirmed in many other studies $(4,9,12,14,26)$.
TABLE 7 | Patient involvement on the national level.

\begin{tabular}{|c|c|c|}
\hline Category & Sweden & The Netherlands \\
\hline \multirow[t]{3}{*}{$\begin{array}{l}\text { National policy's } \\
\text { intended benefits }\end{array}$} & Improve patient empowerment & $\begin{array}{l}\text { Improve medication } \\
\text { safety }\end{array}$ \\
\hline & Improve efficiency of medical services & $\begin{array}{l}\text { Provide information } \\
\text { access for patients }\end{array}$ \\
\hline & Digital "self-service" for patients & \\
\hline \multirow{2}{*}{$\begin{array}{l}\text { Patient- } \\
\text { centeredness of } \\
\text { national policy }\end{array}$} & $\begin{array}{l}\text { NRF version } 1 \text { and } 2 \text { have the same } \\
\text { goals }\end{array}$ & $\begin{array}{l}\text { VIPP is developed for } \\
\text { patients }\end{array}$ \\
\hline & $\begin{array}{l}\text { Access needs to be improved for } \\
\text { persons aged 13-15 }\end{array}$ & \\
\hline \multirow[t]{3}{*}{$\begin{array}{l}\text { Methods/tools for } \\
\text { patient involvement }\end{array}$} & $\begin{array}{l}\text { Workshops with patients and } \\
\text { caregivers }\end{array}$ & \\
\hline & User surveys & \\
\hline & Collecting feedback & \\
\hline \multirow[t]{3}{*}{$\begin{array}{l}\text { Gained } \\
\text { understanding and } \\
\text { insights }\end{array}$} & $\begin{array}{l}\text { Users want direct access to signed } \\
\text { and unsigned notes, preferably in the } \\
\text { professionals' language }\end{array}$ & \\
\hline & $\begin{array}{l}\text { Users want to make their own } \\
\text { decision about viewing the } \\
\text { information with or without delay }\end{array}$ & \\
\hline & $\begin{array}{l}\text { Less negative outcomes for patients } \\
\text { than expected }\end{array}$ & \\
\hline Challenges & $\begin{array}{l}\text { Make compromises between } \\
\text { patients' and HCPs' wishes }\end{array}$ & \\
\hline
\end{tabular}

Even though the resistance presents itself on different levels in Sweden and the Netherlands, the approaches for dealing with it are similar. Both countries felt the need to involve the professionals' viewpoint in decision-making. Even if this compromised the patients' preferences, it was a necessary step to make progress. Multiple Dutch stakeholders perceive involving both the patient and professional perspective as a critical success factor because it is not likely that professionals will be enthusiastic about and use a tool that is created for patients alone and vice versa.

The importance of involving patients' (17, 27-29) and HCPs' perspectives $(26,28)$ in the implementation processes is supported by many studies. Besides stakeholder involvement, the necessity for strong leadership and a gradual approach in implementing were expressed in both countries. Strong leadership is recognized as an important factor for implementation success $(27,30)$, while a gradual implementation strategy can be seen as a way of reducing the HCPs' resistance, for instance, by implementing functionalities or types of information one at a time. However, gradual implementation was viewed as both a barrier and facilitator in Sweden, whereas the delays it caused in the implementation process was only seen as a barrier for Dutch respondents. Another potential solution to $\mathrm{HCP}$ resistance that was mentioned in both countries was enforcing stricter rules or regulations regarding the PAEHR. This is being done, e.g., in the USA, where from April 5, 2021, new federal laws will mandate that providers must extend open notes to all patients, with a few permitted exemptions (31). 
TABLE 8 | Patient involvement on the local implementation level.

\begin{tabular}{|c|c|c|}
\hline Category & Sweden & The Netherlands \\
\hline \multirow[t]{2}{*}{$\begin{array}{l}\text { Importance or } \\
\text { necessity }\end{array}$} & Leads to better care provision & $\begin{array}{l}\text { Added value for patients and } \\
\text { their treatment }\end{array}$ \\
\hline & & To accomplish VIPP \\
\hline \multirow{2}{*}{$\begin{array}{l}\text { Patient- } \\
\text { centeredness } \\
\text { of national } \\
\text { policy }\end{array}$} & $\begin{array}{l}\text { NRF version } 2 \text { is more } \\
\text { transparent and supporting to } \\
\text { patients than version } 1\end{array}$ & $\begin{array}{l}\text { VIPP is developed for } \\
\text { professionals }\end{array}$ \\
\hline & & $\begin{array}{l}\text { Patients will benefit from the } \\
\text { information that is displayed }\end{array}$ \\
\hline \multirow{5}{*}{$\begin{array}{l}\text { Methods/tools } \\
\text { for patient } \\
\text { involvement }\end{array}$} & User surveys & (Online) panels, focus groups \\
\hline & Collecting feedback & User surveys \\
\hline & Patient advisory board & Collecting feedback \\
\hline & Research & Client council members \\
\hline & Assumptions from HCPs & Research and publications \\
\hline \multirow{3}{*}{$\begin{array}{l}\text { Gained } \\
\text { understanding } \\
\text { and insights }\end{array}$} & & $\begin{array}{l}\text { Wishes, needs, complaints } \\
\text { and questions }\end{array}$ \\
\hline & & $\begin{array}{l}\text { Insights into desired future } \\
\text { functionalities }\end{array}$ \\
\hline & & $\begin{array}{l}\text { Debates between client council } \\
\text { members and medical staff, } \\
\text { which sometimes lead to more } \\
\text { support from staff for the } \\
\text { patients' wishes }\end{array}$ \\
\hline \multirow[t]{3}{*}{ Challenges } & $\begin{array}{l}\text { Make compromises between } \\
\text { patients' and HCPs' wishes }\end{array}$ & $\begin{array}{l}\text { Not possible to combine with } \\
\text { VIPP and its technical focus }\end{array}$ \\
\hline & $\begin{array}{l}\text { Few decisions to involve } \\
\text { patients in }\end{array}$ & $\begin{array}{l}\text { Find enough users that are } \\
\text { willing and able to participate, } \\
\text { have the right mindset and are } \\
\text { representative for the hospital's } \\
\text { patient population }\end{array}$ \\
\hline & & $\begin{array}{l}\text { Did not get enough feedback } \\
\text { from patients }\end{array}$ \\
\hline \multirow[t]{3}{*}{$\begin{array}{l}\text { Lack of } \\
\text { resources }\end{array}$} & $\begin{array}{l}\text { Patients had too little } \\
\text { knowledge or experience to } \\
\text { involve in the development } \\
\text { process }\end{array}$ & $\begin{array}{l}\text { Not enough time or other } \\
\text { resources for patient } \\
\text { involvement }\end{array}$ \\
\hline & & $\begin{array}{l}\text { Technically not possible to } \\
\text { meet the patients' wishes and } \\
\text { requirements }\end{array}$ \\
\hline & & $\begin{array}{l}\text { Too many different wishes and } \\
\text { requirements to take into } \\
\text { account }\end{array}$ \\
\hline
\end{tabular}

In Sweden, this could have reduced the inequality in access between regions and let the PAEHR Journalen meet citizens' preferences better. Even though providing digital access is mandatory in the Netherlands from 2020, stricter regulations could have saved time and money that is now needed for convincing HCPs.

Even though technical barriers are reported less often in literature $(32,33)$, they are present on the implementation level in both countries. In the Netherlands, hospitals are dependent on their software vendors for implementing a successful PAEHR and achieving the VIPP goals. Swedish healthcare providers are faced with high integration costs when connecting EHR systems to the HIE. In addition, it is not always possible to show all types of information that are desired due to technical limitations of the EHR systems that are connected to the HIE. Swedish implementers, however, mentioned that sometimes the reuse of protocols and contracts from other regions or healthcare providers is possible, which facilitates the integration. Regions also have the possibility to take note of and learn from social aspects of implementing the PAEHR Journalen in other regions. Dutch hospitals sometimes do the latter as well, whereas technical collaboration appears limited. Even though the majority of Dutch hospitals use one of two large EHR systems and their corresponding patient portal, the implementation of VIPP in practice is dependent on more factors such as the pharmacy's medication system. Learning from peers' implementations seems to be very valuable, but has not been mentioned in literature, as a factor playing a role in the implementation process. Concerns about privacy, security, and authentication are recurrent barriers in literature $(4,14,17,27,29)$, which are surprisingly not mentioned by the respondents in this study. The only barriers related to this domain were about the existing regulations or solutions being too strict and therefore impeding userfriendliness and PAEHR usage.

\section{Patient Involvement}

The most prominent difference in patient involvement between the two countries is not the reasons for or means of doing it but rather the level on which it is performed. The wishes and preferences of Swedish citizens have been studied and known from the beginning of the PAEHR Journalen's development. Until the new version of the NRF came into place, these preferences had, however, not been taken into account. This is due to the compromises that had to be made between patients' and HCPs' preferences in the development of both the national NRF and regional adaptations of the NRF. The new NRF that was agreed upon in 2016 stipulated that the regions should make all information available without delay by 2020 , in accordance with the patients' preferences (34). This is, however, still not the case, and there are so far no consequences for not complying nor incentives to comply. There was little to no patient involvement in developing the Dutch national PAEHR policy, VIPP. Individual hospitals, however, make large efforts in involving users in the development and implementation of their patient portals and even perceive this as a prerequisite for accomplishing VIPP's goals. When doing this, hospitals face different barriers that can be roughly divided into two categories. The first is related to finding the right number of users that are not just willing to participate but also have the right mindset and can together represent the hospital's patient population. The second encompasses barriers that are related to the project itself. These include not having enough time or other resources for patient involvement or not being able to meet the patients' wishes and requirements from either a technical perspective or because there are just too many different wishes and requirements to take into account. Another barrier that cannot be categorized in the previous two groups but that is unforeseen enough to mention is 


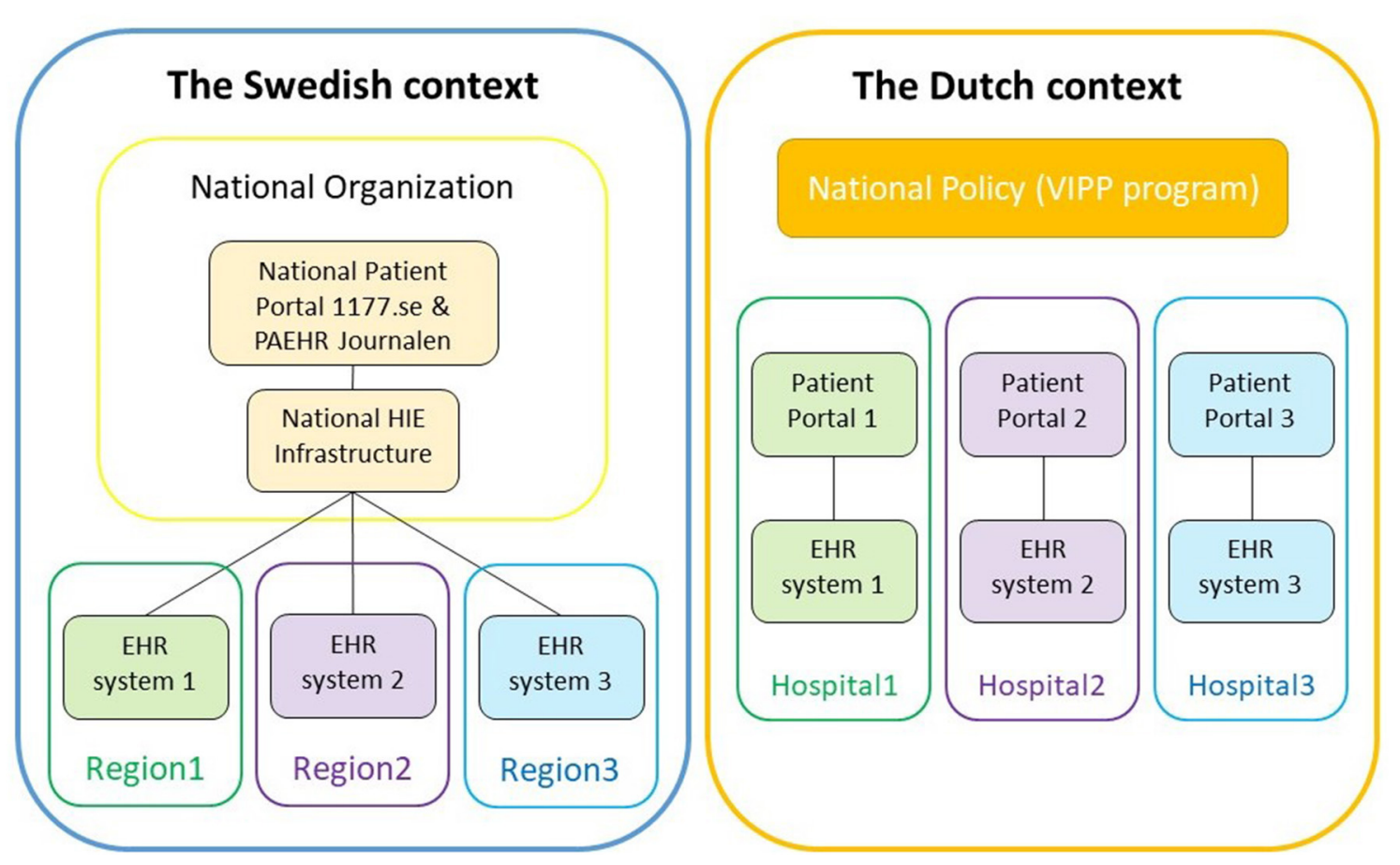

FIGURE 3 | Difference between Sweden's centralized solution and the Netherlands' decentralized.

VIPP itself. The program was set up as an incentive to implement (valuable) PAEHRs, but hospitals report that its technical focus leaves no space for patient involvement.

\section{Centralized vs. Local Implementation in Practice}

One of the most important differences between the Swedish and the Dutch contexts is the centralized approach to PAEHR implementation taken in Sweden $v s$. the local implementation in the Netherlands. Figure 3 gives an overview of the difference.

The centralized solution requires, of course, an agreement from all local healthcare providers (in Sweden, the 21 regions and private healthcare providers) to be integrated with the same infrastructure. It has the added benefit for patients in that they only have one access point; even if they move between regions, their data will be in the same patient portal. The distance between the local implementers and the developers of the national patient portal and PAEHR is, however, quite vast, and it is not easy to make local adaptations or pilot new innovative solutions locally.

The decentralized solution, on the other hand, puts all the responsibility of the development of new patient portals and PAEHRs on the local healthcare providers (hospitals in the Netherlands) and requires quite a commitment on their behalf to actually go through with the implementation. As a patient, you may also have to use different portals if receiving care from different healthcare providers. On the other hand, having a closer distance between the local organizations (the hospital and EHR vendor) may facilitate more rapid development and testing of useful functionality, and a variation in PAEHRs could allow for competition and improvements.

\section{Strengths and Limitations}

The strength of this study is that policymakers and implementers were chosen as respondents, while previous studies have mainly focused on the viewpoints of patients and/or HCPs.

Limitations include the sampling method and conduct of the interviews. Even though attempts were made to interview as many respondents as possible, the respondents were sampled though convenience sampling, and it was not investigated how well the implementers represented the whole implementation level in both countries, yet a limited number of people have deeper insights into the implementation process and the individuals interviewed in each context can be considered experts. It is important to note also that the respondents from the implementation levels from both countries were implementing PAEHRs in different settings within healthcare. The interview respondents that implement VIPP all represent hospitals, while Swedish county councils that implement Journalen are responsible for all levels of healthcare. This may, of course, influence the experienced barriers and facilitators, similar to the way other contextual differences do. Some Swedish respondents were offered to answer the interview questions via email in Swedish, even though the researcher responsible for data collection was not proficient in this language. The answers were translated together with the last author (who is a native Swedish speaker), yet the email interview format led to less detailed questions and answers than in other interviews. However, the respondents' expertise was considered important, and their answers confirmed results from the more in-depth in-person interviews. 


\section{CONCLUSION AND RECOMMENDATIONS}

Most of the major barriers and facilitators that have been mentioned by the PAEHR policy developers and implementers are covered in existing literature, even though previous research generally looked at the viewpoints of patients or HCPs. Our research identified factors that can be seen as more practical and that would not have arisen from interviews with patients or physicians. These include barriers from IT systems and vendors of these systems and the facilitating effect of learning from peers' implementation experiences. While previous literature often mentions concerns about privacy and security as a barrier, this has not been reported by the respondents in this study. We therefore conclude that the factors that affect the PAEHR development and implementation process can differ from the factors that are reported in literature.

We would recommend anyone preparing to implement PAEHRs on a national level or locally in a healthcare organization to consider the factors described in this study when developing and implementing both policy and patient portal/PAEHR. Policy developers can keep the barriers in mind and pave the way for the mentioned facilitators. More specifically, they can consider attaching incentives or penalties to the policy or capturing it in law in order to save resources needed to convince HCPs during implementation. In addition, thoughts can be put into facilitating peer learning among implementers and leaving both room and resources for patient involvement. Implementers should mainly focus on strong leadership, decision-making, and project management, being open to learn from others and allocating resources to possible necessary changes to work practices.

\section{DATA AVAILABILITY STATEMENT}

The datasets presented in this article are not readily available because the data consists of qualitative interview transcripts, and we do not consider this

\section{REFERENCES}

1. Wiljer D, Urowitz S, Apatu E, DeLenardo C, Eysenbach G, Harth T, et al. Patient accessible electronic health records: exploring recommendations for successful implementation strategies. J Med Internet Res. (2008) 10:e34. doi: 10.2196/jmir.1061

2. Delbanco T, Walker J, Bell SK, Darer JD, Elmore JG. Original research inviting patients to read their doctors' notes : a quasiexperimental study and a look ahead. Ann Intern Med. (2012) 157:461-70. doi: 10.7326/0003-4819-157-7-201210020-00002

3. Walker J, Leveille S, Bell S, Chimowitz H, Dong Z, Elmore JG, et al. OpenNotes after 7 years: patient experiences with ongoing access to their clinicians' outpatient visit notes. J Med Internet Res. (2019) 21:e13876. doi: $10.2196 / 13876$

4. Zuniga A V. Patient access to electronic health records: strengths, weaknesses and what's needed to move forward. SLIS Student Res J. (2015) 5:1-9. doi: 10.31979/2575-2499.050103

5. Hägglund M, Scandurra I. Patients' online access to electronic health records: current status and experiences from the implementation in Sweden. Stud Heal Technol Inf. (2017) 245:723-27. doi: 10.3233/978-1-61499-830-3-723 appropriate to make accessible outside the original study. Requests to access the datasets should be directed to maria.hagglund@kbh.uu.se.

\section{ETHICS STATEMENT}

Ethical review and approval was not required for the study on human participants in accordance with the local legislation and institutional requirements. The patients/participants provided their written informed consent to participate in this study.

\section{AUTHOR CONTRIBUTIONS}

$\mathrm{CC}, \mathrm{RC}$, and $\mathrm{MH}$ participated in the design of the study and analysis of the interviews. CC was responsible for data collection and transcribing of interviews. All the authors participated in the writing of the paper, with $\mathrm{CC}$ and $\mathrm{MH}$ taking the main responsibility.

\section{FUNDING}

Partial funding (for MH's work) was provided through the research project PACESS (2016-00623) funded by FORTE-the Swedish Research Council for Health, Working Life and Welfare. This research was also supported by Uppsala MedTech Science \& Innovation (www.medtech.uu.se), a joint strategic initiative between Uppsala University and Uppsala University Hospital.

\section{ACKNOWLEDGMENTS}

We would like to thank the organization behind VIPP, for providing the opportunity to contact potential respondents, as well as all interview respondents, for their participation and valuable input. PACESS is hosted by the DOME consortium which studies the Development of Online Medical Records and eHealth Services.

6. Damschroder LJ, Aron DC, Keith RE, Kirsh SR, Alexander JA, Lowery JC. Fostering implementation of health services research findings into practice: a consolidated framework for advancing implementation science. Implement Sci. (2009) 4:50. doi: 10.1186/1748-5908-4-50

7. Yusof MM, Stergioulas L, Zugic J. Health information systems adoption: findings from a systematic review. Stud Health Technol Inform. (2007) 129:262-6. Available online at: https://ebooks.iospress.nl/publication/ 10975

8. Hägglund M, Scandurra I. A socio-technical analysis of patient accessible electronic health records. Stud Health Technol Inform. (2017) 244:3-7. doi: 10.3233/978-1-61499-824-2-3

9. Beard L, Schein R, Morra D, Wilson K, Keelan J. The challenges in making electronic health records accessible to patients. J Am Med Informatics Assoc. (2012) 19:116-20. doi: 10.1136/amiajnl-2011-000261

10. Moll J, Rexhepi H, Cajander Å, Grünloh C, Huvila I, Hägglund $M$, et al. Patients' experiences of accessing their electronic health records: national patient survey in Sweden. J Med Internet Res. (2018) 20:e278. doi: 10.2196/jmir.9492

11. Rexhepi H, Åhlfeldt R-M, Cajander Å, Huvila I. Cancer patients' attitudes and experiences of online access to their electronic 
medical records: a qualitative study. Health Informatics J. (2016) 24:115-24. doi: 10.1177/1460458216658778

12. Grunloh C, Cajander A, Myreteg G. "The record is our work tool!" physicians' framing of a patient portal in Sweden. J Med Internet Res. (2016) 18:e167. doi: 10.2196/jmir.5705

13. Murray E, Burns J, May C, Finch T, O'Donnell C, Wallace P, et al. Why is it difficult to implement e-health initiatives? A qualitative study. Implement Sci. (2011) 6:6. doi: 10.1186/1748-5908-6-6

14. De Lusignan S, Mold F, Sheikh A, Majeed A, Wyatt JC, Quinn $\mathrm{T}$, et al. Patients' online access to their electronic health records and linked online services: a systematic review in primary care. BMC Open. (2014) 4:e006021. doi: 10.1136/bmjopen-2014006021

15. DesRoches CM, Bell SK, Dong Z, Elmore J, Fernandez L, Fitzgerald $\mathrm{P}$, et al. Patients managing medications and reading their visit notes: a survey of opennotes participants. Ann Intern Med. (2019) 171:6971. doi: $10.7326 / \mathrm{M} 18-3197$

16. Bell SK, Mejilla R, Anselmo M, Darer JD, Elmore JG, Leveille S, et al. When doctors share visit notes with patients: a study of patient and doctor perceptions of documentation errors, safety opportunities and the patient-doctor relationship. BMJ Qual Saf. (2017) 26:26270. doi: 10.1136/bmjqs-2015-004697

17. Irizarry $\mathrm{T}, \mathrm{DeVito}$ Dabbs A, Curran CR. Patient portals and patient engagement: a state of the science review. J Med Internet Res. (2015) 17:e148. doi: 10.2196/jmir.4255

18. Mair FS, May C, O'Donnell C, Finch T, Sullivand F, Murray E. Factors that promote or inhibit the implementation of e-health systems: an explanatory systematic review. Bull World Health Organ. (2012) 90:35764. doi: 10.2471/BLT.11.099424

19. Essén A, Scandurra I, Gerrits R, Humphrey G, Johanssen M, Kierkegaard $\mathrm{P}$, et al. Patient access to electronic health records: differences across ten countries. Heal Technol Policy. 7:44-56. doi: 10.1016/j.hlpt.2017.11.003

20. Scandurra I, Lyttkens L, Eklund B. Implications of Swedish National Regulatory Framework of the Patient Accessible Electronic Health Record. Stud Heal Technol Inf. (2016) 228:695-9. doi: 10.3233/978-1-61499-678-1-695

21. Ministry of Health \& Social Affairs. National eHealth - The Strategy for Accessible and Secure Information in Health and Social Care. (2010). Available online at: www.regeringen.se/sb/d/108/a/148429

22. Davoody N, Koch S, Krakau I, Hägglund M. Accessing and sharing health information for post-discharge stroke care through a national health information exchange platform - a case study. BMC Med Inform Decis Mak. (2019) 19:95. doi: 10.1186/s12911-019-0816-x

23. Sellberg N, Eltes J. The Swedish patient portal and its relation to the national reference architecture and the overall eHealth infrastructure. In: Aanestad M., Grisot M., Hanseth O., Vassilakopoulou P, editors. Information Infrastructures within European Health Care. Health Informatics. Cham: Springer (2017). doi: 10.1007/978-3-319-51020-0_14

24. Scandurra I, Pettersson M, Eklund B, Lyttkens L. Analysis of the updated Swedish regulatory framework of the patient accessible electronic health record in relation to usage experience. Stud Health Technol Inform. (2017) 245:798-802. doi: 10.3233/978-1-61499-830-3-798

25. Renner M, Taylor-Powell E. Analyzing qualitative data. In: Programme Development \& Evaluation. Madison, WI: University of Wisconsin-Extension, Cooperative Extension. Available online at: https://cdn.shopify.com/s/files/1/ 0145/8808/4272/files/G3658-12.pdf (accessed April 16, 2018).

26. Scandurra I, Jansson A, Forsberg-Fransson M-L, Ålander T. Is 'Patient's online access to health records' a good reform? - Opinions from Swedish Healthcare Professionals Differ. Procedia Comput Sci. (2015) 64:9648. doi: 10.1016/j.procs.2015.08.614

27. Ludwick DA, Doucette J. Adopting electronic medical records in primary care: lessons learned from health information systems implementation experience in seven countries. Int J Med Inform. (2009) 78:22-31. doi: 10.1016/j.ijmedinf.2008.06.005

28. Wells S, Rozenblum R, Park A, Dunn M, Bates DW. Organizational strategies for promoting patient and provider uptake of personal health records. $J$ Am Med Informatics Assoc. (2015) 22:213-22. doi: 10.1136/amiajnl-2014-0 03055

29. Gagnon M-P, Payne-Gagnon J, Breton E, Fortin J-P, Khoury L, Dolovich $\mathrm{L}$, et al. Adoption of electronic personal health records in canada: perceptions of stakeholders. Int J Heal Policy Manag. (2016) 5:42533. doi: 10.15171/ijhpm.2016.36

30. Harvey G, Kitson A. PARIHS revisited: from heuristic to integrated framework for the successful implementation of knowledge into practice. Implement Sci. (2016) 11:33. doi: 10.1186/s13012-016-0398-2

31. Salmi L, Blease C, Hägglund $M$, Walker J, DesRoches CM. US policy requires immediate release of records to patients. BMJ. (2021) 372:n426. doi: 10.1136/bmj.n426

32. Pagliari C, Detmer D, Singleton P. Potential of electronic personal health records. BMJ. (2007) 335:330-33. doi: 10.1136/bmj.39279.482963.AD

33. Ancker JS, Miller MC, Patel V, Kaushal R, Investigators with the $\mathrm{H}$. Sociotechnical challenges to developing technologies for patient access to health information exchange data. J Am Med Informatics Assoc. (2014) 21:664-70. doi: 10.1136/amiajnl-2013-002073

34. Hägglund M, Moll J, Åhlfeldt R-M, Scandurra I. Timing it right - patients' online access to their record notes in Sweden. Stud Health Technol Inform. (2018) 247:336-40. doi: 10.3233/978-1-61499-852-5-336

Conflict of Interest: The authors declare that the research was conducted in the absence of any commercial or financial relationships that could be construed as a potential conflict of interest.

Copyright (๑) 2021 Cijvat, Cornet and Hägglund. This is an open-access article distributed under the terms of the Creative Commons Attribution License (CC BY). The use, distribution or reproduction in other forums is permitted, provided the original author(s) and the copyright owner(s) are credited and that the original publication in this journal is cited, in accordance with accepted academic practice. No use, distribution or reproduction is permitted which does not comply with these terms. 